\title{
Prevention of acute ruminal lactic acidosis in sheep by probiotic or monensin supplementation: clinical aspects
}

\section{Prevenção da acidose láctica ruminal aguda em ovinos através da suplementação com leveduras ou monensina: aspectos clínicos}

\author{
Leonardo Frasson dos Reis ${ }^{1}$; Carolina Akiko Sato Cabral de Araujo ${ }^{2 *}$; \\ Rejane Santos Sousa ${ }^{1}$; Antonio Humberto Hamad Minervino ${ }^{3}$; \\ Francisco Leonardo Costa de Oliveira ${ }^{1}$; Frederico Augusto Mazzocca Lopes \\ Rodrigues $^{1}$; Enoch Brandão de Souza Meira-Júnior'; ${ }^{1}$ Raimundo Alves Barrêto- \\ Júnior ${ }^{4}$; Clara Satsuki Mori'; Enrico Lippi Ortolani ${ }^{6}$
}

\begin{abstract}
The aim of this study was to evaluate the effects of two additives (probiotic and monensin) over clinical parameters of sheep submitted to acute ruminal lactic acidosis (ARLA). Eighteen sheeps were divided into three groups of six animals each as follows: probiotic group, supplemented with $4 \times 10^{9} \mathrm{CFU} / \mathrm{animal} /$ day of Saccharomyces cerevisiae; monensin group, supplemented with $33 \mathrm{mg}$ of monensin sodium per $\mathrm{kg}$ of diet; and control group, without any supplementation. After 30 days of diet $(75 \%$ of Coast-cross hay and $25 \%$ concentrate with $14 \%$ of crude protein) and additive intake, ARLA was induced in the all animals by intraruminal administration of $15 \mathrm{~g}$ of sucrose per kilogram $(\mathrm{kg})$ of body weight. Complete physical examinations to assess the vital signs of the animals were conducted at the following times: baseline (T0), six (T6h), 12 (T12h), 18 (T18h), 24 (T24h), 36 (T36h), and 48 (T48h) hours after ARLA induction. At those times, blood samples were obtained to determine the plasma volume deficit (PVD) and ruminal content for $\mathrm{pH}$ measurement. All animals experienced clinical signs of ARLA with ruminal $\mathrm{pH}$ lower than 4.9 at $\mathrm{T} 24 \mathrm{~h}$. The heart rate and PVD were lower $(\mathrm{P}<0.05)$ in the probiotic group at T36h. Compared to the control and monensin groups, the probiotic group experienced milder ARLA characterized by lower degrees of dehydration and fewer clinical symptoms.
\end{abstract}

Key words: Ionophore. Saccharomyces cerevisiae. Supplement. Symptoms.

\footnotetext{
1 Médicos Veterinários, Discentes, Faculdade de Medicina Veterinária e Zootecnia, Universidade de São Paulo, FMVZ-USP, São Paulo, SP, Brasil. E-mail: leofrasson@gmail.com; rejane.santossousa@gmail.com; oliveiraflc@usp.br; fredones@hotmail.com, enochmj@gmail.com

2 Médica Veterinária, Prof ${ }^{\mathrm{a}}$ Dra $^{\mathrm{a}}$, Universidade Federal Rural de Pernambuco, UFRPE, Recife, PE, Brasil. E-mail: carolcbpr@ gmail.co

3 Médico Veterinário, Prof. Dr., Laboratório de Sanidade Animal, Universidade Federal do Oestes do Pará, LARSANA/UFOPA, Santarém, PA, Brasil. E-mail: ah.minervino@gmail.com

4 Médico Veterinário, Prof. Dr., Departamento de Ciência Animal, UFERSA, Mossoró, RN, Brasil. E-mail: barreto@ufersa.edu.br

5 Química, Pesquisadora, Faculdade de Medicina Veterinária e Zootecnia, FMV-ZUSP, São Paulo, SP, Brasil. E-mail: clarasat@ usp.br

6 Médico Veterinário, Prof. Titular, Faculdade de Medicina Veterinária e Zootecnia, FMVZ-USP, São Paulo, SP, Brasil. E-mail: ortolani@usp.br

* Author for correspondence
} 


\section{Resumo}

Objetivou-se avaliar os efeitos de dois aditivos (probiótico e monensina sódica) sobre a parâmetros clínicos de ovinos submetidos a acidose láctica ruminal aguda (ALRA). Dezoito ovinos foram divididos em três grupos com seis animais cada assim constituídos: Probiótico, suplementado com $4 \times 10^{9}$ ufc/ animal/dia de Saccharomyces cerevisiae; Monensina, suplementado com $33 \mathrm{mg} / \mathrm{kg}$ de monensina sódica; Controle, sem aditivo. Após 30 dias de oferecimento da dieta ( $75 \%$ feno de Coast-cross e $25 \%$ concentrado com $14 \%$ de proteína bruta) e aditivos, os animais foram submetidos à indução de ALRA por meio da administração intraruminal de 15 gramas de sacarose por $\mathrm{kg}$ de peso vivo. Foi realizado exame físico completo nos animais com aferição dos parâmetros vitais nos seguintes momentos: basal (T0), seis (T6h), doze (T12h), 18 (T18h), 24 (T24h), 36 (T36h) e 48 (T48h) horas após a indução da ALRA. Em todos os momentos de avaliação foram obtidas amostras de sangue para determinação do déficit de volume plasmático (DVP) e de conteúdo ruminal para aferição do $\mathrm{pH}$. Todos os animais apresentaram quadro de ALRA com $\mathrm{pH}$ ruminal menor que 4,9 no T24h, sem diferença entre os grupos $(\mathrm{p}=0.092)$. A frequência cardíaca e o DVP foram inferiores $(\mathrm{P}<0,05)$ no grupo Probiótico no T36h. Os animais do grupo Probiótico apresentaram quadro de ALRA mais branda observada por menor grau de desidratação e menor ocorrência de sintomas clínicos em relação aos animais dos grupos controle e monensina.

Palavras-chave: Aditivo. Ionóforo. Saccharomyces cerevisiae. Sintomas.

\section{Introduction}

Owing to the increase in sheep rearing that focuses on intense weight gain in a short period, animals are subjected to diets that include large amounts of concentrates, which predispose them to several metabolic disorders (SILVA et al., 2009; OLIVEIRA et al., 2015a). In a retrospective study at Mato Grosso do Sul state, pregnancy toxemia and acute ruminal lactic acidosis (ARLA) were the most common metabolic disorders found in sheep (ALMEIDA et al., 2013)

Acute ruminal lactic acidosis (ARLA) is caused by the sudden intake of carbohydrates, especially when the rumen environment is not adapted. The ingestion of such diets stimulates rumen fermentation, and consequently, short chain fatty acids (SCFA) and lactic acid are produced that result in $\mathrm{pH}$ reduction and increase in rumen osmolarity that may lead to clinical disorders such as hyporexia, ruminal atony and dehydration (BARRETO JÚNIOR et al., 2008; ORTOLANI et al., 2008, 2010; MINUTI et al., 2014; OLIVEIRA et al., 2015b).
Initially, hyporexia occurs, which is followed by changes in the general state such as apathy and depression. Ruminal atony is observed in many affected animals, while some may experience low muscle tone movements as one of the symptoms. This atony of rumen is considered a defense mechanism since without movements the absorption of acids is reduced (BRAUN et al., 1992; LETTAT et al., 2010).

Because of ruminal lactic acid absorption, systemic metabolic acidosis develops and the clinical signs accentuate. Tachycardia and tachypnea may occur in animals with mild metabolic acidosis in which the blood $\mathrm{pH}$ remains above 7.18 (RADOSTITS et al., 2007; LASKOSKI et al., 2014). Further, in cases of severe acidosis, respiratory frequency may decrease (DIRKSEN et al., 2005).

Signs of dehydration are observed in animals with ARLA, as liquids are directed to the ruminal lumen (RADOSTITS et al., 2007). The mucous membranes become hyperemic and the episcleral vessels become congested. If dehydration becomes severe, a dry muzzle, enophtalmia, low skin temperature at 
the extremities, oliguria, or anuria is also observed (DIRKSEN et al., 2005; RODRIGUES et al., 2011). The clinical signs observed in sheep are similar to those observed in cattle, although bruxism and muscle fasciculation have been reported in sheep with acidosis (OLIVEIRA et al., 2015b).

To avoid clinical and ruminal metabolism effects of ARLA in animals subjected to carbohydrate-rich diets are the addition of ionophore compounds or probiotics to the total feed (AFONSO et al., 2002; NAGARAJA; LECHTENBERG, 2007). The ionophore monensin has a selective action on bacteria such that Gram-negative bacteria can survive, while Gram-positive bacteria are inhibited (NAGARAJA et al., 1982). The Saccharomyces cerevisiae probiotics stimulate specific rumen bacteria populations, promote an increase in the cellulolytic bacteria number, stabilize the rumen $\mathrm{pH}$, and increase both the fiber digestibility and the anaerobic conditions (BACH et al., 2007; DESNOYERS et al., 2009; LETTAT et al., 2012).

Although the above-mentioned supplements have been recommended for preventing ARLA in ruminants, more challenging studies that evaluate the metaphylactic effects of probiotic and monensin supplements under similar conditions in sheeps with ARLA symptoms are unavailable. Furthermore, considering the concerns regarding dietetic antibiotics utilization for sheeps and other ruminants, the yeast-based probiotic could be a substitute option for monensin to prevent ARLA in challenged animals. Thus, the aim of this study was to evaluate the clinical outcome of sheeps subjected to experimental induction of ARLA that received previously Saccharomyces cerevisiae probiotics or ionophore monensin sodium.

\section{Material and Methods}

We used 18 male, adult, Santa Ines crossbred sheeps with an average body weight (BW) of 45 $\pm 3.2 \mathrm{~kg}$. All animals underwent rumen silicone cannula implantation surgery and received moxidectin-based endectocide (Cydectin sheep ${ }^{\circledR}$, Fort Dodge, Campinas, Brazil). The animals underwent a 60-day recovery period and were adapted to the experimental conditions after the surgical procedures.

During the adaptation period and study course, sheeps were kept in individual metabolic cages and were fed a basal diet calculated as per $2.7 \%$ of BW and composed of $75 \%$ dry matter of Coast-cross grass hay (Cynodon dactylon) and 25\% commercial concentrate (Fri-Sheep 22/70, Nutreco Animal Nutrition, Pitangueiras, Brazil). Diet was fractioned and offered twice a day. Animals had free access to water.

The 18 animals were subjected to a completely random experimental design in which, after the adaptation period, the animals were randomly divided into three groups of six animals each as follows: control, probiotic, and monensin group. The control group received only the basal diet, whereas the probiotic group received additionally $5 \mathrm{~g} \mathrm{~d}^{-1}$ of Yea-Sacc ${ }^{\circledR} 1026$ (Alltech SA, Araucária, Brazil) that provided an inoculation of $4 \times 10^{9} \mathrm{CFU}$ animal $^{-1}$ day $^{-1}$ of $S$. cerevisiae strain 1026, and the monensin group received $33 \mathrm{mg}$ of monensin sodium per $\mathrm{kg}$ of diet (Rumensin $^{\circledR}$, Elanco, Greenfield, USA) as recommended by Afonso et al. (2002). Both monensin and probiotic were administered directly into the rumen ate the same time of animal feed to ensure that the doses of the additives were consumed correctly.

Experimental induction of ruminal lactic acidosis has been performed by using an experimental cattle model, which involved sucrose administration directly into the rumen (ORTOLANI, 1995); following specific modifications for sheep as recommended by Afonso et al. (2002), with administration of $15 \mathrm{~g}$ of sucrose per kilogram of BW directly into the rumen. Acidosis was induced after the animals spent 30 consecutive days in their allocated experimental groups and received diets with probiotics, monensin, or basal diet for controls. 
Physical and ruminal examination were conducted at the following time intervals: baseline (T0), immediately before induction of ARLA; after 6 hours (T6h); 12 hours (T12h); 18 hours (T18h); 24 hours (T24h); 36 hours (T36h); and 48 hours (T48h) of induction of ARLA. Physical examinations of the animals throughout the experiment were conducted by the same trained professional; the heart rate (HR), respiratory rate (RR), ruminal movements (RM), hydration status, and any clinical change that could eventually occur were assessed following the recommendations described by Dirksen et al. (1993) and Pugh (2004). Fresh grass was offered at each moment of clinical examination to the animals, to assess their appetite, which was evaluated if the animals had interest and ingest the grass. Rumen content samples were collected throughout ruminal fistula at the same time intervals for $\mathrm{pH}$ determination (Gehaka, PG 1800, São Paulo, SP, Brazil).

Since physiological values of globular volume (GV) show large individual variations among animals, plasma volume deficit (PVD) was studied for an adequate assessment of the degree of animal dehydration during the experiment. For this purpose, whole blood samples were obtained by jugular venipuncture by using vacuum tubes with EDTA after clinical evaluation. The whole blood samples were used for GV determination by using the microhematocrit technique (JAIN, 1986). To determine the PVD, the following formula proposed by Kaneko et al. (1997) was used: PVD $=\{[G V 1$ (1 - GV2) / GV2 × (1-GV1)] - 1\} × 100; where GV1 $=$ initial $\mathrm{GV}$ at $\mathrm{T} 0$ and $\mathrm{GV} 2=\mathrm{GV}$ at the other times.

To protect the welfare of the animals, all sheep that exhibited clinical signs of systemic acidosis such general depression, severe dehydration and had blood $\mathrm{pH} \leq 7.2$ (data not showed) were treated after the examination and sample collection at $\mathrm{T} 24 \mathrm{~h}$ (REIS et al., 2018). The treatment for systemic acidosis included infusion of sodium bicarbonate (1.3\%) isotonic solution according to the formula for buffer replacement (RADOSTITS et al., 2007), and $20 \mathrm{~mL} / \mathrm{kg}$ of body weight (BW) of isotonic saline solution.

For statistical analyses, all the variables were initially subjected to the Kolmogorov-Smirnov normality test. The parameters exhibited a normal distribution and were subjected to analysis of variance followed by Tukey post-hoc test to assess differences among experimental groups in each time interval. Paired T test was applied to compare the time intervals with baseline (T0) within the same group. To evaluate the relationships among the experimental groups and the frequency of clinical events, the $\chi^{2}$ test was performed. The relationships between pairs of variables were analyzed through regression analysis and coefficient of determination $\left(r^{2}\right)$ calculation. A significance level of $5 \%$ was adopted. All the statistical analysis was performed using Prisma software ${ }^{\circledR}$ (version 6.0, Graph Pad Inc., La Jolla, USA)

\section{Results and Discussion}

The experimental model adopted was successful, and the control group experienced clinical symptoms that were associated with ruminal lactic acidosis in sheep. Data from ruminal and blood parameters were publish elsewhere (REIS et al.,2018). The mean $\mathrm{pH}$ values for the rumen contents at $\mathrm{T} 24 \mathrm{~h}$ were $4.25,4.79$, and 4.85 for the control, monensin, and probiotic group, respectively, without statiscal difference $(\mathrm{P}=0.092)$ among groups, values that characterize rumen lactic acidosis, as previously publish report by Reis et al. (2018). The probiotic group showed faster recovery of the ruminal $\mathrm{pH}$, returning to normal values at $\mathrm{T} 36 \mathrm{~h}$ (mean $\mathrm{pH}=$ 6.36); the ruminal $\mathrm{pH}$ values of the monensin group were 5.47 and 6.41 after 36 and 48 hours, respectively. The control group presented ruminal $\mathrm{pH}$ values about 4.76 and 5.70 after 36 and 48 hours of the induction and showed values significant different in relation to probiotics group $(\mathrm{P}<0.001)$.

Figure 1 shows the results of the average values and the respective standard deviations of the HR, 
$\mathrm{RR}$, and $\mathrm{RM}$ of the control, monensin, and probiotic groups throughout the experiment. The HR at T36h was lower in animals that received probiotics compared to that in the control animals $(\mathrm{P}<0.05)$. The HR was increased at T6h (control group) or $\mathrm{T} 12 \mathrm{~h}$ (monensin and probiotic groups) returning to baseline values at $\mathrm{T} 48 \mathrm{~h}$ in all groups $(\mathrm{P}<0.001)$.
The HR was influenced by the PVD $\left(r^{2}=0.49 ; y\right.$ $\left.=-0,0035 x^{2}+0,7562 x+90,551\right)$. Ortolani et al. (2010) described that an increase in the HR can be interpreted as a systemic compensatory response to hypovolemia that leads to a decrease in blood pressure, which in turn leads to sinus tachycardia.

Figure 1. Mean values and standard deviations of the heart rate (HR), respiratory rate (RR), and ruminal movements (RM) of sheep that received monensin and probiotic supplements and were subjected to experimental induction of ruminal lactic acidosis. Different letters in the same experimental period indicate the differences between groups observed by the Tukey test $(\mathrm{P}<0.005)$.
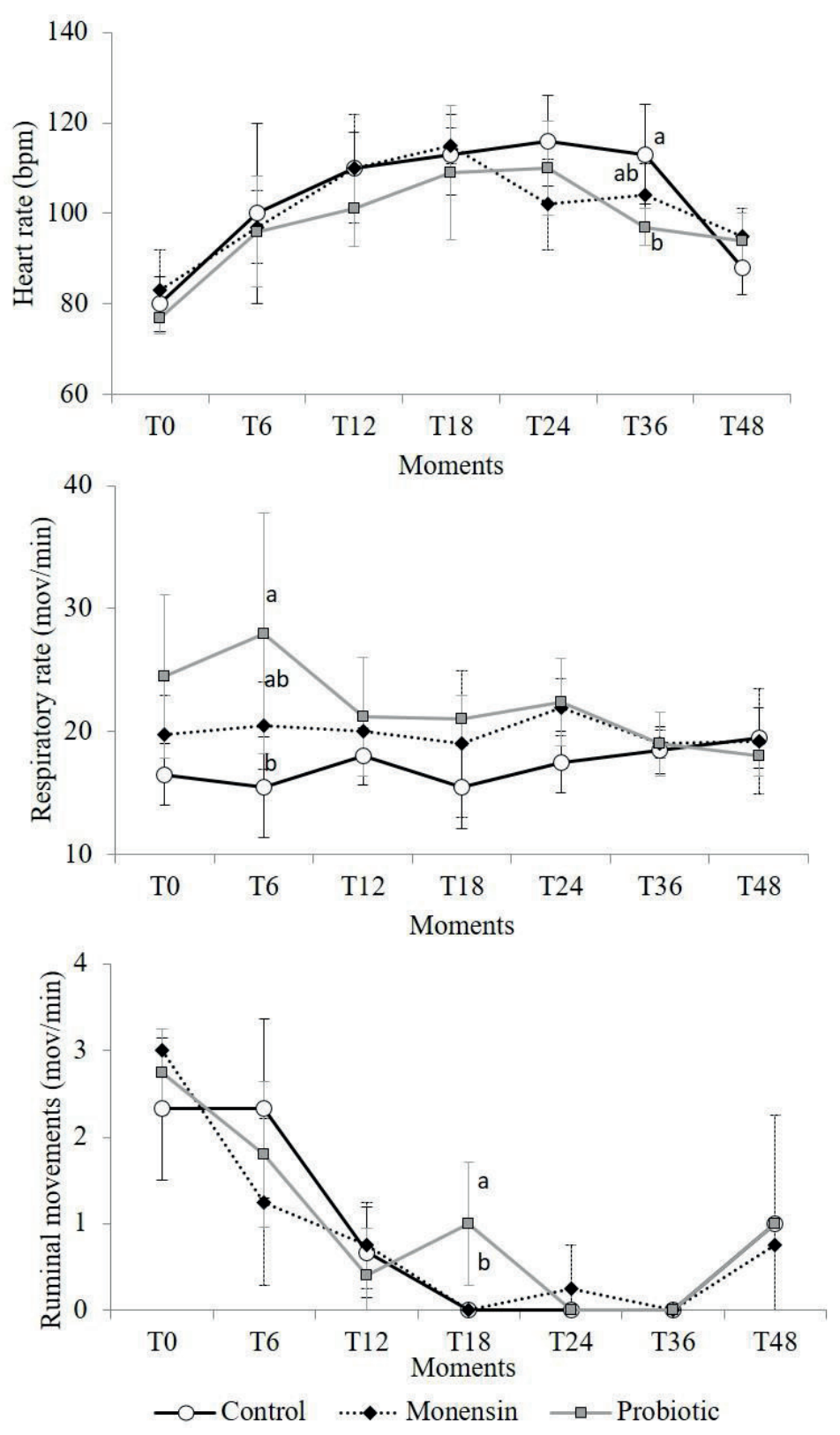
With respect to the $\mathrm{RR}$, there was an increase in the average values in the probiotic group only at T6h $(\mathrm{P}<0.05)$ in relation to control group, which was probably associated with an isolated event of manipulation stress without further clinical relevance. No statistical difference was observed in the RR between the evaluation times.

The RM decreased during the induction as expected. According to Huber (1976), ruminal stoppage is a defense mechanism of the animal; the greater the rumen motility, the greater will be the ruminal lactic acid absorption, especially that of the isomer D (MARUTA; ORTOLANI, 2002). Animals that received probiotics took longer to present ruminal atony, which occurred in all groups at $\mathrm{T} 24 \mathrm{~h}$ and $\mathrm{T} 36 \mathrm{~h}$, presenting a higher RM $(\mathrm{P}<$ $0.05)$ at $\mathrm{T} 18 \mathrm{~h}$ in relation to the other groups. This can be explained by the fact that no animal in this group experienced appetite loss or depression of the general condition. The ingestion of roughage stimulates rumen movements.

Figure 2 shows the PVD values observed in this study. All animals during the experiment had some degree of dehydration that was represented by the increase in PVD values. Some sheep from the control and monensin groups exceeded $40 \%$ of PVD that exhibited clear clinical symptoms of more pronounced dehydration, which was characterized by enophthalmia, dry muzzle, marked loss of skin elasticity, low skin temperature in the extremities, and oliguria (DIRKSEN et al., 2005; RADOSTITS et al., 2007; VIEIRA et al., 2012). The decrease in PVD observed after T24h occurred because of the treatment (hydration) of the animals, required in two sheep's from control group, two from monensin and one sheep from probiotic group.

Figure 2. Mean values and standard deviations of plasma volume deficit (\%) of sheep that received monensin and probiotic supplements and were subjected to experimental induction of ruminal lactic acidosis. Different letters in the same experimental period indicate the differences between groups observed by the Tukey test $(\mathrm{P}<0.005)$.

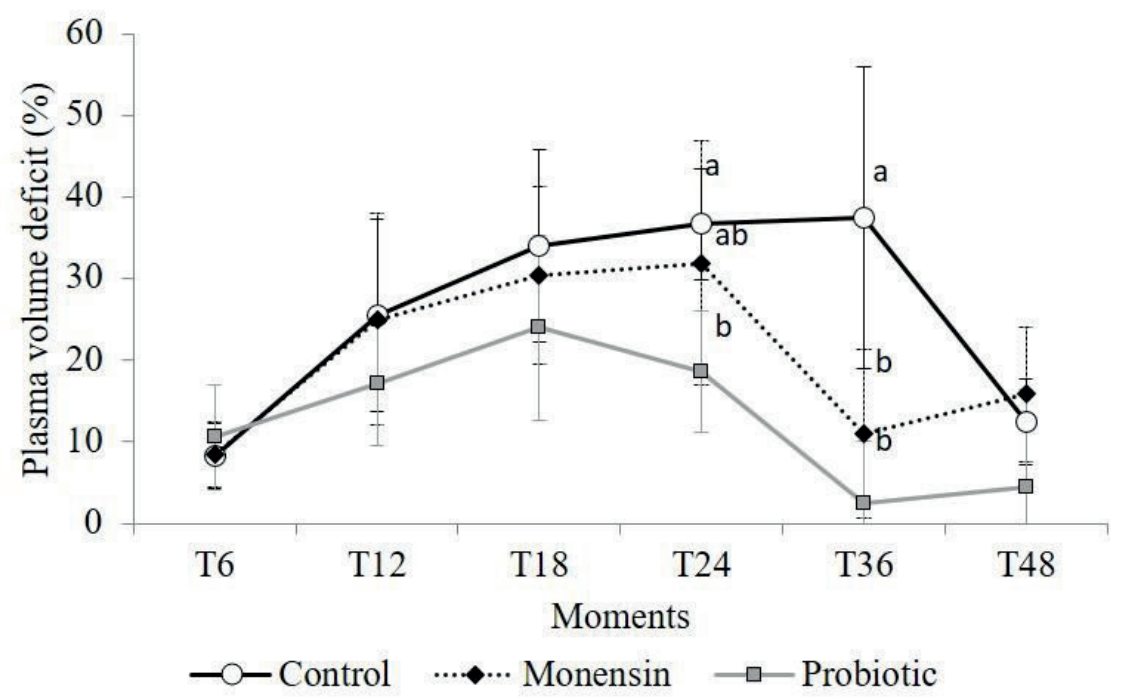


Dehydration caused by ruminal acidosis originates from the sharp increase in ruminal osmolality compared to blood osmolarity, which leads to the passage of fluids through the rumen (MIRANDA NETO et al., 2011; RODRIGUES et al., 2011). It is suggested that the lower degree of dehydration observed in the probiotic group $(\mathrm{P}<$ $0.05)$ is associated with the consumption of lactic acid by the yeasts present in the probiotic, which could reduce rumen osmolarity and, consequently, the flow of fluids from the blood to the rumen (RODRIGUES et al., 2011).
Table 1 shows the frequencies of different clinical events observed during the study course. One animal of each group experienced diarrhea during the experiment. More severe dehydration symptoms were not observed in the three animals that experienced diarrhea. Ortolani et al. (2010) reported that $100 \%$ of the bovine models subjected to acidosis induction by sucrose had diarrhea, while in the present study only $16.6 \%(\mathrm{n}=3)$ of the sheeps showed the symptom, which was probably because of the differences in the induction methodology that included a smaller amount of sucrose being administered to the sheep's.

Table 1. Clinical events observed in animals of different groups throughout the experiment.

\begin{tabular}{lcccc}
\hline Clinical event & Control n (\%) & Monensin n (\%) & Probiotic n (\%) & Total* $\mathrm{n}(\%)$ \\
\hline Diarrhea & $1(16.6)$ & $1(16.6)$ & $1(16.6)$ & $3(16.6)$ \\
Appetite loss after 24 hours & $3(50.0)$ & $2(33.3)$ & - & $5(27.7)$ \\
Laminitis & $1(16.6)$ & $3(50.0)$ & $1(16.6)$ & $5(27.7)$ \\
General depression & $3(50.0)$ & $2(33.3)$ & - & $5(27.7)$ \\
Severe dehydration & $3(50.0)$ & $2(33.3)$ & - & $5(27.7)$ \\
\hline Total & $11^{\mathrm{a}}$ & $10^{\mathrm{a}}$ & $2^{\mathrm{b}}$ & - \\
\hline
\end{tabular}

* Number of occurrences relative to the 18 animals of the three experimental groups.

Different letters in the same line indicate differences by the $\chi^{2}$ test $(P=0.007)$.

Laminitis was observed in $22.2 \%(n=4)$ of the 18 animals with ruminal lactic acidosis; of these, one animal belonged to the control group, and three belonged to the monensin group. According to Nocek (1997), ruminal acidosis may cause the generation of ruminal endotoxins from bacterial death, which when absorbed can generate aseptic inflammation in the sensitive and corium laminae in some animals with ARLA.

The clinical results of this study indicate that probiotic intake after ARLA induction at T24h may have contributed to the recovery of the rumen environment and control of colonies of bacteria that produce acids such lactic acid, which may be the reason for the fewer clinical symptoms observed in probiotics group (BACH et al., 2007).
Probiotics had a metaphylactic action that developed milder acidosis with fewer clinical events $(\mathrm{P}=0.007)$ in probiotic group compared to that developed in the other groups. No animal of the probiotic group had appetite loss or depression of the general condition.

\section{Conclusions}

The use of probiotics led to milder ARLA clinical signs in sheep then control and monensin groups by decreasing the degree of dehydration, number of clinical events and by promoting a faster stabilization of the ruminal $\mathrm{pH}$ to its normal values. 


\section{Acknowledgements}

We thank FAPESP for financial support (Process: 2010/08371-0)

Araujo, C. A. S. C. is grateful to FAPESP for the $\mathrm{PhD}$ scholarship granted.

\section{Ethics Committee and Biosafety}

This study was approved by the Ethics Committee on Animal Use of the Faculty of Veterinary Medicine and Animal Science, University of São Paulo, Protocol No 1587/2009

\section{References}

AFONSO, J. A. B.; CIARLINI, P. C.; KUCHEMBUCK, M. R.G.; KOHAYAGAWA, A.; FELTRIN, L. P. Z.; CIARLINI，L. D. R.; PINOTI，L.; CECÍLIA，B.; MENDONÇA, C. L.; TAKAHIRA, R. K. Metabolismo oxidativo dos neutrófilos de ovinos tratados com monensina sódica e experimentalmente submetidos à acidose ruminal. Pesquisa Veterinária Brasileira, Seropédica, v. 22, n. 4, p. 129-134, 2002.

ALMEIDA, T. L.; BRUM, K. B.; LEMOS, R. A. A.; LEAL, C. R. B.; BORGES, F.A. Doenças de ovinos diagnosticadas no Laboratório de Anatomia Patológica Animal da Universidade Federal de Mato Grosso do Sul (1996-2010). Pesquisa Veterinária Brasileira, Seropédica, v. 33, n. 1, p. 21-29, 2013.

BACH, A.; IGLESIAS, C.; DEVANT, M. Daily rumen $\mathrm{pH}$ pattern of loose-housed dairy cattle as affected by feeding pattern and live yeast supplementation. Animal Feed Science and Technology, Amsterdam, v. 136, n. 1-2, p. 146-153, 2007.

BARRETO JÚNIOR, R. A.; MINERVINO, A. H. H.; RODRIGUES, F. A. M. L.; ANTONELLI, A. C.; SUCUPIRA, M. C. A.; MORI, C. S.; ORTOLANI, E. L. Avaliação do potencial da polpa cítrica em provocar acidose láctica ruminal aguda em bovinos. Brazilian Journal of Veterinary and Animal Science, São Paulo, v. 45 , n. 6, p. 421-428, 2008.

BRAUN, U.; RIHS, T.; SHEFER, U. Ruminal lactic acidosis in sheep and goats. The Veterinary Record, London, v. 130, n. 6, p. 343-349, 1992.

DESNOYERS, M.; GIGER-REVERDIN, S.; BERTIN, G.; DUVAUX-PONTER, C.; SAUVANT, D. Metaanalysis of the influence of Saccharomyces cerevisiae supplementation on ruminal parameters and milk production of ruminants. Journal of Dairy Science, Champaign, v. 92, n. 4, p. 1620-1632, 2009.

DIRKSEN, G.; GRUNDER, H.; STOBER, M. ROSENBERGER: exame clínico dos bovinos. $3^{\text {th }}$ ed. Rio de Janeiro: Guanabara Koogan S.A., 1993. 419 p.

DIRKSEN, G.; GRÜNDER, H. D.; STÖBER, M. Medicina interna $y$ cirugia del bovino. $4^{\text {th }}$ ed. Buenos Aires: Intermédica, 2005. 632 p.

HUBER, T. L. Physiological effects of acidosis on feedlot cattle. Journal of Animal Science, Champaign, v. 43, n. 4, p. 902-909, 1976.

JAIN, N. C. Schalm's veterinary hematology. Philadelphia: Lea \& Febiger, 1986. 1221 p.

KANEKO, J. J.; HARVEY, J. W.; BRUSS, M. L. Clinical biochemistry of domestic animals. $5^{\text {th }}$ ed. New York: Academic Press, 1997. 932 p.

LETTAT, A. P.; NOZIÈRE, M.; SILBERBERG, D. P.; MORGAVI, C.; BERGER, C. M. Experimental feed induction of ruminal lactic, propionic, or butyric acidosis in sheep. Journal of Animal Science, Champaign, v. 88, n. 9, p. 3041-3046, 2010.

Rumen microbial and fermentation characteristics are affected differently by bacterial probiotic supplementation during induced lactic and subacute acidosis in sheep. BMC Microbiology, London v. 12, n. 142, p. 1-12, 2012.

LASKOSKI, L. M.; MURARO, L. S.; SANTANA JÚNIOR, M. S.; CARVALHO, M. B.; FREITAS, S. H.; DÓRIA, R. G. S.; SANTOS, M. D.; DITTRICH, R. L. Sodium bicarbonate as prevention of metabolic acidosis in sheep submitted to experimental ruminal acidosis. Pesquisa Veterinária Brasileira, Seropédica, v. 34, n. 9, p. 822-826, 2014.

MARUTA, C. A.; ORTOLANI, E. L. Susceptibilidade de bovinos das raças Jersey e Gir à acidose láctica ruminal: I - variáveis ruminais e fecais. Ciência Rural, Santa Maria, v. 32, n. 1, p. 55-59, 2002.

MINUTI, A.; AHMED, S.; TREVISI, E.; PICCIOLICAPPELLI, F.; BERTONI, G.; JAHAN, N.; BANI, P. Experimental acute rumen acidosis in sheep: Consequences on clinical, rumen, and gastrointestinal permeability conditions and blood chemistry. Journal of Animal Science, Champaign, v. 92, n. 9, p. 3966-3977, 2014.

MIRANDANETO, E. G.; SILVA, S. T. G.; MENDONÇA, C. L.; DRUMMOND, A. R. F.;AFONSO, J.A. B. Aspectos clínicos e a bioquímica ruminal de caprinos submetidos à acidose láctica experimental e suplementados ou não 
com monensina sódica. Pesquisa Veterinária Brasileira, Seropédica, v. 31, n. 5, p. 416-424, 2011.

NAGARAJA, T. G.; AVERY, T. B.; BARTLEY, E. E.; ROOF, S. K.; DAYTON, A. D. Effect of lasalocid, monensin or thiopeptin on lactic acidosis in cattle. Journal of Animal Science, Champaign, v. 54, n. 3, p. 649-658, 1982.

NAGARAJA, T. G.; LECHTENBERG, K. F. Acidosis in feedlot cattle. Veterinary Clinics of North America: Food Animal Practice, Maryland Heights, v. 23, n. 2, p. 333350, 2007.

NOCEK, J. E. Bovine acidosis: implications on laminitis. Journal of Dairy Science, Champaign, v. 80, n. 5, p. 1005-1028, 1997.

OLIVEIRA, F. L. C.; BARRÊTO-JÚNIOR, R. A.; MINERVINO, A. H. H.; REIS, L. F.; ARAÚJO, C. A. S. C.; RODRIGUES, F. A. M. L.; SOUSA, R. S.; GAMELEIRA, J. S.; SOUZA, F. J. A.; MORI, C. S.; ORTOLANI, E. L. Avaliação hemogasométrica, bioquímica e hematológica de ovinos suplementados com melão. Arquivo Brasileiro de Medicina Veterinária e Zootecnia, Belo Horizonte, v. 67, n. 5, p. 1272-1278, 2015a.

OLIVEIRA, F. L. C.; BARRÊTO-JÚNIOR, R. A.; MINERVINO, A. H. H.; REIS, L. F.; TAVARES, M. D.; VALE, R. G.; GAMELEIRA, J. S.; SOUZA, F. J. A.; MORI, C. S.; ORTOLANI, E. L. Avaliação clínica de ovinos não adaptados submetidos à ingestão súbita de melão com alto teor de açúcar. Semina: Ciências Agrárias, Londrina, v. 36, n. 6, p. 3721-3730, 2015 b.

ORTOLANI, E. L. Induction of lactic acidosis in cattle with sucrose: relationship between dose, rumen fluid $\mathrm{pH}$ and animal size. Veterinary and Human Toxicology, Manhattan, v. 37, n. 5, p. 462-464, 1995.

ORTOLANI, E. L.; MARUTA, C. A.; MINERVINO, A. H. H._Influência da raça sobre a volemia e função renal de bovinos com acidose láctica ruminal aguda, induzida experimentalmente. Brazilian Journal of Veterinary Research and Animal Science, São Paulo, v. 45, n. 6, p. 451-457, 2008.
Quadro clínico de zebuínos e taurinos submetidos à acidose láctica ruminal aguda. Brazilian Journal of Veterinary Research and Animal Science, São Paulo, v. 47, n. 4, p. 253-261, 2010.

PUGH, D. G. Clínica de ovinos e caprinos. São Paulo: Roca, 2004. 513 p.

RADOSTITS, O. M.; GAY, C. C.; HINCHCLIFF, K. W.; CONSTABLE, P. D. Veterinary medicine. $10^{\text {th }}$ ed. London: Elsevier Saunders, 2007. 2156 p.

REIS, L. F.; SOUSA, R. S.; OLIVEIRA, F. L. C.; RODRIGUES, F. A. M. L.; ARAÚJO, C. A. S. C.; MEIRA-JÚNIOR, E. B. S.; BARRÊTO-JÚNIOR, R. A.; MORI, C. S.; MINERVINO, A. H. H.; ORTOLANI, E. L. Comparative assessment of probiotics and monensin in the prophylaxis of acute ruminal lactic acidosis in sheep. BMC Veterinary Research, London, v. 14, n. 9, p. $1-8,2018$.

RODRIGUES, F. A. M. L.; MINERVINO, A. H. H.; BARRÊTO JÚNIOR, R. A.; ANTONELLI, A. C.; REIS, L. F.; ARAÚJO, C. A. S. C.; FERREIRA, R. N. F.; VECHIATO, T. A. F.; MORI, C. S.; ORTOLANI, E. L. Avaliação clínica do uso de solução salina hipertônica no tratamento de acidose láctica ruminal aguda em bovinos. Brazilian Journal of Veterinary Research and Animal Science, São Paulo, v. 48, n. 6, p. 446-453, 2011.

SILVA, N. S.; SILVEIRA, J. A. S.; CAMPOS, K. F.; SOUSA, M. G. S.; LOPES, C. T. A.; OLIVEIRA, C. M. C.; DUARTE, M. D.; BARBOSA, J. D. Acidose ruminal em ovinos, diagnosticada pela central de diagnóstico veterinário (CEDIVET) da Universidade Federal do Pará, no período de 2000 a 2008. In: CONGRESSO BRASILEIRO DE BUIATRIA, CIÊNCIA ANIMAL BRASILEIRA, 8., 2009. Anais... Belo Horizonte: Escola de Veterinária e Zootecnia da UFG, 2009. p. 191-196.

VIEIRA, A. C.; CÂMARA, A. C.; MENDONÇA, C. L.; AFONSO, J.A. B. Hematological and biochemical profile of sheep supplemented with salinomycin and submitted to experimental lactic ruminal acidosis. Ciência Animal Brasileira, Goiânia, v. 13, n. 2, p. 259-271, 2012. 
